and his students was central to his character." Another former student fondly recalled that his first seminar with Professor Turner shifted the entire focus of his graduate program by "instilling in me a lifelong joy in studying American politics and public policy. He engaged students in thought-provoking discussions-one mark of an outstanding teacher."

Henry Turner's research and writings centered on American politics and included some two dozen articles and several books, including coauthorship of American Democracy in World Perspective, which went through five editions.

This academic record won Henry recognition in the form of awards from the Ford Foundation, the Rockefeller Foundation, and the American Philosophical Society. In 1962-63, he taught at the University of Khartoum in Sudan. On Fulbright grants, he taught in 1968 at Witwatersrand University in Johannesburg, South Africa; and in 1974, at Tehran University in Iran, under a grant from the U.S. State Department. He also taught summer session courses at the Universities of Missouri, Nebraska, and California, Berkeley. Beginning in 1966, he was listed in every edition of Who's Who in America.

Also notable was Henry Turner's participation in university governance. He was the first UCSB faculty member to serve on the Editorial Board of the University of California Press, being twice appointed to that body. He also served on several UCSB Academic Senate committees, including the important Committee on Academic Personnel, which he chaired in his third and final year. This led to his appointment for two years (1971-73) as acting vice chancellor for Academic Affairs.

Heart surgery in 1974, during which he received blood tainted by the hepatitis- $C$ virus, caused increasing health problems. Nevertheless, he continued teaching on a phasedretirement basis until 1987, when he officially retired from UCSB after 39 years of service. That same year, he was selected as Alumnus of the Year at Northwest University in Missouri.
Henry Turner is survived by his devoted wife of fifty-five years, Mary, as well as by three grown children and seven grandchildren. His family and many friends will remember him especially for his dedication, integrity, fairness, and consideration for others.

Gordon E. Baker
University of California, Santa Barbara
Robert Casier
University of California, Santa Barbara
Stephen Wiener
University of Califomia, Santa Barbara

\section{Marcia Lynn Whicker}

Marcia Lynn Whicker, chair of the graduate department of public administration at Rutgers University, Newark died on March 23, 1999 , after a long battle with cancer. She was only 51 . She came to RutgersNewark in 1992, after having taught at Virginia Commonwealth University, the University of South Carolina, Temple University, and Wayne State University. She received an M.P.A. from the University of Tennessee, an M.S. in economics from the University of Kentucky, and her Ph.D. in political science from the University of Kentucky in 1976. She was an APSA Congressional Fellow in 1975. Since becoming department chair at Rutgers-Newark in 1994, she devoted much of her time and energy to administrative duties and accomplished a great deal in a relatively short time.

Throughout her academic career, Marcia had a deep commitment to teaching and to her students. She spent untold hours mentoring her graduate students and working closely with them to ensure their success. She often collaborated with her students on papers and articles. Shortly before her death, when she was told that the department wanted to honor her in some way, Marcia supported the idea of a scholarship fund in her name for M.P.A. students at Rutgers. This has now been established by the department.

Marcia had a deep commitment to research and was a prolific scholar. She authored, coauthored, or edited sixteen books, published 40 peer-reviewed articles and thirty book chapters, and wrote many other articles and papers. Her research reflected the great breadth of her interests, but it had several central themes. She described two of them as the impact of government structures on policy outputs, using both simulations and real world settings, and leadership, resulting in books on both the presidency and state legislative leaders.

During her years as a graduate student at the University of Kentucky, we found that she was full of thoughtful and perceptive questions, curious about almost everything, and quick to absorb information about things she knew little about. Her curiosity and love of exploring new ideas were lifelong characteristics. Marcia wanted to know everything, especially about how things work, and in the course of trying to find out she would literally devour huge literatures. Then she would try to integrate what she knew and think about what she didn't know, and try to figure out how to maximize the former and minimize the latter. Her first instinct was to resist imposing limits and constraints on inquiry, to try to swallow very large subjects rather than chewing on them bit by bit. This may have helped account for her devotion to simulation as a conceptual tool, which allowed her to rearrange things in ways that the real world was too limited to permit. For her, the intellectual thrill was in seeing the big picture; writing it down was a boring chore. She was incredibly enthusiastic about whatever set of ideas occupied her at a given time, and was endlessly involved in organizing projects, recruiting collaborators, finding book publishers. And then she would move along to other things.

Marcia made friends widely and took pains to maintain contact long after she left an institution or a coauthorship was completed. The advent of email was a great boon to Marcia's nurturing of friendships. Sometimes, her messages were devoted to political science, but they could just as easily be about politics, films, pop psychology, you name it. It was not unusual to communicate 
a simple thought or ask a simple question by email and to have Marcia respond with many screens, providing extensive answers to the question, and then expanding the conversation both professionally and personally. For Marcia cared about her friends and took a deep interest in their professional and personal successes and difficulties. She was never too busy, in the midst of writing, traveling, administering, teaching, et cetera to send a birthday card to a friend, probably with some little trinket she had bought, or one of her poems or paintings. She was a prolific purchaser of both art and odds and ends from garage sales. Each of us has a collection of gifts that she barraged us with over the years from her own work and her purchases.

Marcia was wonderful to talk toopen, engaging, uninhibited, enthusiastic, smart, down-to-earth, interested, interesting, and kind. She was brimming with ideas, thrived on conversation, and was always concerned about her friends. She was full of life. For those who have been her students, colleagues, and collaborators, and for her wide circle of friends, Marcia's death has left a void that will never really be filled.

Michael A. Baer

American Council on Education Bradley C. Canon University of Kentucky Malcolm E. Jewell University of Kentucky Lee Sigelman George Washington University 